\title{
Requerimientos energéticos de ovinos de pelo en las regiones tropicales de Latinoamérica. Revisión
}

\author{
Energy requirements of hair sheep in the tropical regions \\ of Latin America. Review
}

\author{
Alfonso Juventino Chay-Canula, Juan Gabriel Magaña-Monforteb, Mario Luiz Chizzottic, \\ Angel Trinidad Piñeiro-Vázquezb, Jorge Rodolfo Canul-Solísd, Armin Javier \\ Ayala-Burgosb, Juan Carlos Ku-Verab, Luis Orlindo Tedeschie
}

\begin{abstract}
RESUMEN
Los ovinos de pelo juegan un papel importante en la producción animal en las regiones tropicales; sin embargo, sus requerimientos nutricionales no se han determinado en la misma medida que los de las razas de lana. Debido a las condiciones ambientales de las regiones tropicales (clima, calidad y disponibilidad de alimentos), es razonable la hipótesis de que los requerimientos de energía metabolizable (EM) y la eficiencia de utilización de la EM pueden ser diferentes entre los ovinos de razas de pelo y de lana. La información disponible en ovinos de pelo muestra una gran discrepancia en cuanto a las necesidades de energía. Con base en datos de la literatura disponible para hembras ovinas, el requerimiento de EM para mantenimiento $\left(\mathrm{EM}_{\mathrm{m}}\right.$ ) fue de $419 \pm 129 \mathrm{~kJ} / \mathrm{kg} \mathrm{PC} 0.75$ (media \pm desviación estándar) y para machos fue $388 \pm 123 \mathrm{~kJ} / \mathrm{kg}$ BW0.75. El requerimiento de energía neta para la ganancia de peso (EN $\mathrm{g}$ ) varió de 8.75 a $14.06 \mathrm{~kJ} / \mathrm{g}(11.63 \pm 1.86 \mathrm{~kJ} / \mathrm{g})$. Las eficiencias de utilización de la EM para el mantenimiento $\left(k_{m}\right)$ y la ganancia de peso $\left(k_{g}\right)$ fueron de $0.66 \pm 0.023$ y $0.42 \pm 0.044$, respectivamente. Esta revisión también indicó que la información es escasa para ovejas adultas en diferentes etapas fisiológicas (mantenimiento, lactancia y gestación). Se requiere más trabajo de investigación con relación a la estimación de las necesidades de energía de los ovinos de pelo, con el fin de hacer ajustes a los modelos existentes de alimentación, con el objetivo de predecir la respuesta de los animales con la condición que prevalece en los trópicos (tipo de animal, medio ambiente y alimentos disponibles).
\end{abstract}

PALABRAS ClAVE: Ovinos de pelo, Requerimientos de energía, Trópicos, Mantenimiento, Ganancia, Eficiencia.

\begin{abstract}
Breeds of hair sheep play an important role in animal production in tropical regions; however, their nutrient requirements have not been determined to the same extent as those of wool breeds. Due to the environmental conditions of the tropical regions (climate, quality and availability of feedstuffs), it is reasonable to hypothesize that energy requirements and efficiency of utilization of metabolizable energy (ME) may be different between hair and wool breeds of sheep. Information available on hair sheep shows a large discrepancy regarding energy requirements. Based on available literature data for female sheep, ME requirement for maintenance $\left(\mathrm{ME}_{\mathrm{m}}\right) \mathrm{was}^{419 \pm 129 \mathrm{~kJ} /}$ kgBW0.75 (mean \pm standard deviation) and for the male $388 \pm 123 \mathrm{~kJ} / \mathrm{kg} \mathrm{BW} 0.75$. The requirement of net energy for gain $\left(\mathrm{NE}_{g}\right)$ ranged from 8.75 to $14.06 \mathrm{~kJ} / \mathrm{g}(11.63 \pm 1.86 \mathrm{~kJ} / \mathrm{g})$. The efficiency of ME utilization for maintenance $\left(k_{m}\right)$ and gain $\left(k_{g}\right)$ were $0.66 \pm 0.02$ and $0.42 \pm 0.04$, respectively. This review indicated also that information is scarce for adult ewes at different physiological stages (maintenance, lactation, or pregnancy). More work is required regarding estimates of nutrient requirements of hair sheep in order to develop adjustments to existing nutrition models to predict animal's response under the conditions prevailing in the tropics (animal type, environment and feedstuffs available).
\end{abstract}

KEY WORDS: Hair sheep, Energy requirements, Tropics, Maintenance, Gain, Efficiency.

Recibido el 23 de enero de 2015. Aceptado el 17 de abril de 2015.

a División Académica de Ciencias Agropecuarias, Universidad Juárez Autónoma de Tabasco. Carretera Villahermosa-Teapa, km 25, CP 86280. Villahermosa, Tabasco, México. aljuch@hotmail.com; ajchc19@yahoo.com.mx. Correspondencia al primer autor.

b Facultad de Medicina Veterinaria y Zootecnia, Universidad Autónoma de Yucatán. Mérida, Yucatán, México.

c Universidade Federal de Viçosa, Viçosa, MG 36571. Brazil.

d Instituto Tecnológico de Tizimín. Departamento de Investigación y Posgrado. Tizimín, Yucatán, México.

e Department of Animal Science, Texas A\&M University, College Station. USA. 


\section{INTRODUCCIÓN}

La producción ovina en las regiones tropicales de América Latina y el Caribe ha aumentado en los últimos años. Los sistemas de producción en estas regiones se caracterizan por baja productividad y las razas empleadas son en su mayoría ovinos de pelo. Desde un punto de vista comparativo con razas de lana, las razas de pelo son pequeñas, con una tasa de crecimiento lenta y mala conformación muscular, por lo tanto, éstas se han cruzado para mejorar la tasa de crecimiento(1). Razas de pelo como Dorper y Katahdin muestran altas tasas de crecimiento y se han introducido en sistemas de cría con las razas Pelibuey y Blackbelly utilizadas en México(2).

A pesar de la importancia de las razas de pelo en la producción ovina tropical y del mundo, sólo pocos experimentos se han realizado para determinar sus requerimientos de energía $(3,4,5)$. Conocer las necesidades de nutrientes y la eficiencia de utilización de los recursos alimenticios es importante para optimizar la productividad y lograr el comportamiento productivo esperado $(5,6,7)$. Sin embargo, con frecuencia se publican valores y modelos de predicción de requerimientos, basados en razas de clima templado $(5,7,8,9)$ con resultados en la producción animal diferentes de lo esperado, así como la incapacidad para predecir el comportamiento productivo del animal. En este sentido(10) recientemente en ovejas Santa Inês se ha demostrado la importancia de la utilización de ecuaciones específicas a las condiciones locales para asegurar que se realicen predicciones precisas y confiables de consumo de materia seca. Además, algunos estudios han indicado que las razas ovinas de pelo tienen diferentes requerimientos de energía en comparación con las razas de lana, pero esta afirmación se ha basado en datos experimentales limitados(11).

Por otro lado, el consumo de energía por los ovinos se considera como el primer nutriente limitante para el crecimiento(12). Además, el

\section{INTRODUCTION}

Sheep production in the tropical regions of Latin America and the Caribbean has increased during recent years. Production systems in those regions are characterized by low-inputs, and breeds employed are mostly hair sheep. From a comparative standpoint with wool breeds, breeds of hair sheep are small, with a slow growth rate and poor muscular conformation, therefore, these have been crossed to improve rate of growth(1). Hair breeds such as Dorper and Katahdin show high rates of growth and have been introduced in breeding schemes with the Pelibuey and Blackbelly breeds commonly used in Mexico(2).

In spite of the importance of hair breeds in tropical and world sheep production, only few experiments have been carried out to assess their energy requirements $(3,4,5)$. Knowledge of nutrient requirements and efficiency of utilization of feed resources is important to optimize productivity and achieve expected performance $(5,6,7)$. However, frequently published values and prediction models of requirements, are based on breeds from temperate environments $(5,7,8,9)$ with results in animal performance different from what is expected and the inability to predict animal performance. In this sense(10) recently demonstrated the importance of using specific equations to local conditions to ensure that accurate and reliable predictions of dry matter intake by Santa Inês sheep are made. Also, some studies have stated that hair sheep breeds have different energy requirements compared to wool breeds, but this assertion has been based on limited experimental data(11).

On the other hand, energy intake by sheep is considered to be the first limiting nutrient for growth(12). Moreover, insufficient energy supply to the animal results in slow growth, older age at puberty, reduced fertility, decreased milk production and greater susceptibility to nematodes. In adult animals, when energy intake is lower than that required for 
suministro de energía insuficiente se refleja en lento crecimiento, mayor edad a la pubertad, reducción en fertilidad, menor producción de leche y una mayor susceptibilidad a los nematodos. En animales adultos, cuando la ingesta energética es menor que la necesaria para el mantenimiento, el animal utiliza sus reservas corporales de energía(13), especialmente de grasa, y cuando esto ocurre en exceso, enfermedades metabólicas como cetosis pueden surgir. Al final de la gestación y principio de la lactancia, también se puede presentar un desequilibrio energético, que induce al animal a utilizar sus reservas energéticas corporales para producción de leche(14).

En la actualidad, debido a que los principales recursos para la producción animal (tierra, agua) están más limitados en algunas regiones del mundo, la determinación precisa de nutrientes requeridos por los animales es de suma importancia para evitar la pérdida de estos recursos(12). El NRC(15) incluye ovinos de pelo en la base de datos para predecir la ganancia diaria de peso (GDP). El sistema Cornell de carbohidratos y proteína netos para ganado ovino (CNCPS-S, por sus siglas en inglés) o el sistema de nutrición de pequeños rumiantes (SRNS, por sus siglas en inglés) $(12,16)$ han sido evaluados para la predicción de GDP en ovinos Pelibuey $(6,17)$ y GDP y consumo de materia seca en ovinos Santa Inês $(18,19,20)$ y ajustes a dichos modelos han sido propuestos para que sean comparables a los de Pelibuey $(6,17)$. Costa et a/(21) informaron que es necesario tener una base de datos que pueda ser actualizada con frecuencia, por medio de meta-análisis, de tal manera que los modelos desarrollados tengan incorporados datos recientes. Tedeschi et a/(12) concluyen que se requieren más datos que permitan una mejora en la precisión de los modelos de predicción basados en el SNRS bajo condiciones de producción diferentes. Sin embargo, la información disponible para ovinos de pelo es escasa y sin actualizar. En México se conoce poco con respecto a sus requerimientos para mantenimiento y ganancia de peso y la maintenance, the animal uses its own body energy reserves(13), particularly fat and when this occurs in excess, metabolic diseases such as ketosis may arise. At the end of pregnancy and beginning of lactation, there may also occur an energy unbalance which induces the animal to use its own body energy reserves for milk production(14).

At present, due to the fact that the main resources for animal production (land, feed, water) are more limited in some regions of the world, precise determination of nutrient required by the animals is of paramount importance to avoid waste of these resources(12). The NRC(15) includes hair sheep in the database used to predict daily weight gain (DWG). The Cornell Net Carbohydrate and Protein System for sheep (CNCPS-S) or Small Ruminant Nutrition Systems (SRNS) $(12,16)$ have been evaluated for the prediction of DWG in Pelibuey sheep $(6,17)$ and DWG and dry matter intake in Santa Inês sheep $(18,19,20)$, and adjustments to such models have been proposed to make them comparable to those of Pelibuey sheep $(6,17)$. Costa et al(21) reported that it is necessary to have a database which can be updated frequently, by means of a meta-analysis in such a way that models developed have recent data incorporated. Tedeschi et al(12) concluded that it is necessary more data which allow an improvement to be realized in the precision of prediction models based on the SRNS under different production conditions. However, the available information for hair sheep is scattered and outdated. Very littlle is known in Mexico regarding metabolizable energy (ME) requirements of hair sheep for maintenance and weight gain and the efficiency with which ME is utilized for both physiological functions. The knowledge of such information may help to improve the efficiency of sheep production under practical conditions in sheep farms thus improving farm profitability.

The aim of the present review was to analyze available information on ME requirements and efficiency of its utilization for maintenance and weight gain in hair sheep kept under tropical 
eficiencia con la que la energía metabolizable (EM) se utiliza para ambas funciones fisiológicas. El conocimiento de tal información puede ayudar a mejorar la eficiencia de la producción ovina bajo condiciones prácticas en las explotaciones ovinas, mejorando la rentabilidad de la explotación.

El objetivo de la presente revisión fue analizar la información disponible sobre los requerimientos de EM y la eficiencia de utilización para mantenimiento y ganancia de peso en ovinos de pelo mantenidos bajo condiciones tropicales en América Latina, con el fin de visualizar las áreas potenciales de investigación que puedan llevar hacia un mejor conocimiento de los requerimientos nutricionales de estos ovinos.

Situación de la producción de ovinos de pelo

En los principales países productores de ovinos de América Latina y el Caribe, las razas de ovinos y fenotipos son diversos, y se describen generalmente como "Criollos", recibiendo diferentes nombres dependiendo de donde estén ubicados, y en algunos casos la misma raza se nombra de diferentes maneras; por ejemplo el Pelibuey o Tabasco se cría en México, en las conditions in Latin America, in order to visualize potential areas of research which may lead towards a better understanding of nutrient requirement by hair sheep.

\section{Situation of hair sheep production}

In the main sheep producing countries in Latin America and the Caribbean, the phenotypes and breeds of sheep are diverse and they are generally described as "Creole", and receive different names depending on where they are located and in some cases the same breed is named in different ways, for example the Pelibuey or Tabasco breed in Mexico, in the Virgin Islands the Pelo Blanco or Saint Croix breed, in Tobago West African or Roja Africana breed are the same. In Brazil there are three breeds of hair sheep: Morada Nova, Somali Brasileño and Santa Inês. Table 1 shows the breeds of hair sheep and their distribution in Latin America. Mature weight by sex of each breed was taken from the "Breeds of Livestock" website (www.ansi.okstate.edu/breeds/) of the Animal Science Department at Oklahoma State University(15). According to NRC(15), in order to obtain a more precise prediction of energy requirements, it is necessary to consider mature weight of the animals, as this is associated

Cuadro 1. Razas de ovinos de pelo y su distribución en América Latina

Table 1. Breeds of hair sheep and their distribution in Latin America

\begin{tabular}{llccl}
\hline Breed & Other names & \multicolumn{2}{l}{ MW (kg) } & Distribution \\
& & Male & Female & \\
\hline Africana & Pelona, Camura, Red African, Rojo Africana, & & & \\
& Colombian Wooless, West African & & Colombia and Venezuela \\
Blackbelly & Barriga negra & 60 & $32-44$ & Mexico, Caribbean \\
Dorper & - & & 60 & Mexico and Brazil \\
Katadhin & - & $70-90$ & $55-70$ & Mexico, Dominican Republic, Haiti \\
Morada Nova & - & 40 & 30 & Brazil \\
Pelibuey & Carnero de pelo de buey, Cuban hairy, Cubano rojo, & & & \\
Rabo largo & Peligüey, Tabasco & 54 & 34 & Cuba, Mexico and Caribbean \\
Santa Inês & - & - & - & Brazil \\
Somali Brasileño & Somali Brasileiro, Rabo gordo & $80-100$ & $60-70$ & Brazil \\
St. Croix & Virgin Island White, White Virgin Islander, White Virgin Island & 100 & $35-45$ & British Islands, Virgin Islands, in the Caribbean \\
\hline
\end{tabular}

$M W=$ Mature weight, taken from the web site: www.ansi.okstate.edu/breeds/. 
Islas Vírgenes las razas Pelo Blanco o Saint Croix, en Tobago la raza Roja Africana y West African son las mismas. En Brasil hay tres razas de ovinos de pelo: Somalí Brasileño, Morada Nova y Santa Inês. El Cuadro 1 muestra las razas de ovinos de pelo y su distribución en América Latina. El peso adulto por sexo de cada raza se tomó de la página Web de "Razas de ganadería" (del www.ansi.okstate.edu/ breeds/) del Departamento de Ciencia Animal de la Universidad del estado de Oklahoma(15). Según la NRC(15), para obtener una predicción más precisa de las necesidades energéticas, es necesario considerar el peso adulto de los animales, ya que éste está asociado con la composición del tejido retenido según el porcentaje de peso adulto del animal, que varía entre razas y genotipos. En ovinos, se ha reportado que los requerimientos de EM para mantenimiento disminuyen conforme el animal va creciendo, que está relacionado con la proporción obtenida del peso adulto(15).

Requerimientos de energía para mantenimiento y crecimiento

Para la creación de la base de datos, se realizó una revisión de literatura con Science Direct with composition of the retained tissue depending on the percentage of mature weight of the animal, which varies among breeds and genotypes. In sheep, it has been reported that ME requirements for maintenance decrease as the animal gets older, which is related with the proportion achieved of mature weight(15).

Data on energy requirements for maintenance and growth of hair sheep

A literature review using the Science Direct (http://www.sciencedirect.com/), and Google Scholar (http://scholar.google.com/) search engines was conducted to create a database, and papers published in the scientific literature were obtained from journals such as: Tecnica Pecuaria en Mexico, Brazilian Journal of Animal Science, Ciência Agrotecnica, Small Ruminant Research, Semina: Ciências Agrárias and Italian Journal of Animal Science. The method by means the ME requirement for maintenance and growth was estimated is also presented in Table 2. It can be appreciated that the work carried out with hair sheep was performed with regression and comparative slaughter techniques; different to what has been done

Cuadro 2. Descripción de la base de datos utilizada en esta revisión

Table 2. Description of the database used in this review

\begin{tabular}{lccclll}
\hline Author & $\mathrm{N}$ & Breed & Method & Country & Sex and physiological stage & Range LW (kg) \\
\hline$(3)$ & 24 & $\mathrm{~Pb}$ & $\mathrm{CS}$ & Mexico & Male, growing & $29.6 \pm 1.58$ \\
$(40)$ & 40 & $\mathrm{Ra} \times \mathrm{Pb}$ & $\mathrm{REG}{ }^{2}$ & Mexico & Castrated male and growing ewes, grazing & $13.5 \pm 0.80$ \\
$(4)$ & 17 & $\mathrm{SI}$ & $\mathrm{CS}$ & Brazil & Castrated male, growing lambs & 20 to 35 \\
$(38)$ & 13 & $\mathrm{SI}$ & $\mathrm{CS}$ & Brazil & Male, growing & 15 to 45 \\
$(8)$ & 30 & $\mathrm{MN}$ & $\mathrm{CS}$ & Brazil & Male, growing & 15 to 25 \\
$(32)$ & 1112 & $\mathrm{~Pb}$ & $\mathrm{REG} 1$ & Mexico & Male, growing & 21.6 to 34.9 \\
$(32)$ & 192 & $\mathrm{~Pb}$ & $\mathrm{REG} 1$ & Mexico & Female, growing and beginning of pregnancy. & 27.7 to 34.0 \\
$(7)$ & 32 & $\mathrm{Sl}$ & $\mathrm{CS}$ & Brazil & Castrated male, growing, grazing & 15.8 to 30 \\
$(31)$ & 22 & $\mathrm{~Pb}$ & $\mathrm{CS}$ & Mexico & Adult females & 35 to 37 \\
$(18,22)$ & 24 & $\mathrm{SI}$ & $\mathrm{CS}$ & Brazil & Male, growing & 12.35 to 30.30 \\
$(34)$ & 48 & $\mathrm{MN}$ & $\mathrm{CS}$ & Brazil & Male, growing & 12.5 to 25.9 \\
$(20)$ & 35 & $\mathrm{SI}$ & $\mathrm{CS}$ & Brazil & Male, growing & 14.77 to 28 \\
$(30)$ & 84 & $1 / 2 \mathrm{Do} \times 1 / 2 \mathrm{SI}$ & $\mathrm{CS}$ & Brazil & Male growing lambs & 18.0 to 45 \\
$(26)$ & 48 & $\mathrm{BS}$ & $\mathrm{CS}$ & Brazil & Male growing lambs & 13.47 to 28.71 \\
\hline
\end{tabular}

$\mathrm{Pb}=$ Pelibuey; Ra= Rambouillet; $\mathrm{SI}=$ Santa Inês; MN= Morada Nova; Do= Dorper; $\mathrm{BS}=$ Brazilian Somali.

$C S=$ Comparative slaughter; $R E G^{1}=$ Regression of $M E$ intake on changes in live weight, in experiments published in the literature; REG2= Regression of $M E$ intake on changes in live weight (with original data from the experiments). 
(en http://www.sciencedirect.com/) y motores de búsqueda de Google Scholar (del http:// scholar.google.com/) así como artículos publicados en la literatura científica de revistas tales como: Técnica Pecuaria en México, Revista Brasileña de Zootecnia, Ciência Agrotecnica, Small Ruminant Research, Semina: Ciências Agrarias y Revista Italiana de Ciencia Animal. El método por el cual se estimó la EM requerida para mantenimiento y crecimiento también se presenta en el Cuadro 2. Se aprecia que el trabajo realizado con ovinos de pelo se ha realizado con regresión y técnicas de sacrificio comparativo; lo que difiere a lo realizado con ovinos de lana, en los cuales sus necesidades de energía se han obtenido básicamente con técnicas calorimétricas(23-26). Hay que iniciar trabajos calorimétricos con ovejas de pelo en las regiones tropicales para validar los datos obtenidos por regresión y técnicas de sacrificio comparativas.

Requerimientos de energía y eficiencia en la utilización de EM para mantenimiento

Los costos de energía para el mantenimiento representan entre el 60 y el $80 \%$ del total de energía consumida por rumiantes(25). Los requerimientos de energía y en particular los de mantenimiento (Em), así como la eficiencia de utilización del alimento y la energía contenida en los tejidos (adiposo, muscular) en el ganado, ha sido un tema de investigación durante varias décadas $(25,27)$. El requerimiento de EM para mantenimiento (EMm), puede ser comparado al Ilamado "metabolismo basal" (en su mayoría utilizado en la alimentación humana), y se define como la cantidad de energía que el animal necesita para mantener los procesos vitales (funciones [corazón, pulmón, renal, nervioso, "trabajo"] y las funciones celulares [grasa y proteína; intercambio de iones de $\mathrm{Na} / \mathrm{K}]$ ) del cuerpo en condiciones normales. En la práctica, el EMm podría definirse como el estado en el que el animal no sufre cambios en su composición corporal $(9,23)$. También se ha definido como el estado en que el consumo de EM (CEM) no resultará en pérdidas o ganancias with wool sheep, since the energy requirements of these sheep has been obtained basically with calorimetric techniques(23-26). There is a need to initiate calorimetric work with hair sheep in tropical regions to validate the data obtained by regression and comparative slaughter techniques.

Energy requirements and efficiency of $M E$ utilization for maintenance $\left(k_{m}\right)$

Energy costs for maintenance represent between 60 and $80 \%$ of total energy consumed by ruminants(25). Energy requirements and in particular those for maintenance $\left(E_{m}\right)$, as well as the efficiency of feed utilization and the energy contained in tissues (adipose, muscular) in cattle has been a research subject during several decades $(25,27)$. The requirement of metabolizable energy (ME) for maintenance $\left(\mathrm{ME}_{m}\right)$, can be equated to the so-called "basal metabolism" (mostly used in human nutrition) and is defined as the amount of energy that the animal needs in order to maintain vital processes (basic functions [heart, lung, kidney, nervous, "work"] and cellular functions [fat and protein turnover; $\mathrm{Na} / \mathrm{K}$ ion pump]) of the body under normal conditions. In a practical way, the $\mathrm{ME}_{m}$ could be defined as the state in which the animal does not suffer changes in its body composition $(9,23)$. It has also been defined as the state in which ME intake (MEI) will not result in loses or gains of energy (RE) in the animal body tissues; Ferrell and Oltjen(28) define this unit as, $M E_{m}=M E I$ at which $R E=0$; or $H P$ (heat production $)=$ MEI.

Among the factors which influence $E_{m}$ : body weight (BW), breed, sex, physiological condition, nutritional level, environmental conditions, stress, exercise, or physical activity and parasitism can be listed $(9,15)$. The efficiency of utilization of $\mathrm{ME}_{\mathrm{m}}\left(k_{m}\right)$ represents that fraction of ME which can be converted to net energy (NE), to support maintenance requirements of the ruminant. The fraction which is no converted to NE is lost as heat increment including 
de energía (ER) en los tejidos del cuerpo animal; Ferrell y Oltjen(28) definen esta unidad como, $\mathrm{EMm}=\mathrm{CEM}$ en el que $\mathrm{ER}=0$; o $\mathrm{PC}$ (producción de calor $)=$ CEM.

Entre los factores que influyen en el Em se pueden mencionar: peso corporal (PC), raza, sexo, estado fisiológico, nivel nutricional, condiciones ambientales, estrés, ejercicio o actividad física y parasitismo $(9,15)$. La eficiencia de la utilización de $\mathrm{EMm}\left(K_{m}\right)$ representa la fracción de EM que se puede convertir en energía neta (EN), para soportar los requerimientos de mantenimiento de los rumiantes. La fracción que no se puede convertir a EN se pierde como el incremento de calor incluyendo fermentación en el tracto gastrointestinal y reacciones fermentation in the gastrointestinal tract and biochemical reactions at the cellular level(29). The efficiency of energy utilization of feedstuffs has an economic impact, and the best way to determine it is by means of feed conversion efficiency $(27,30)$.

Table 3 shows estimations of $\mathrm{ME}$ and NE requirements for maintenance $\left(\mathrm{ME}_{\mathrm{m}}\right.$ and $\mathrm{NE}_{\mathrm{m}}$ respectively) and Table 4 shows efficiencies of ME utilization for maintenance $\left(k_{m}\right)$ estimated in hair sheep of different breeds under tropical conditions of Latin America.

It is important to point out that for the case of ewes, in the present review only two experiments were found which were related to

Cuadro 3. Requerimientos energéticos para mantenimiento estimados en ovinos de pelo en condiciones tropicales de América Latina

Table 3. Energy requirements for maintenance estimated in hair sheep in tropical conditions of Latin America

\begin{tabular}{|c|c|c|c|c|c|c|}
\hline $\begin{array}{l}\text { Sex, breed and } \\
\text { physiological stage }\end{array}$ & $\begin{array}{l}\text { Relationship } \\
\text { BW/EBW }\end{array}$ & $\mathrm{ME}_{\mathrm{m}}(\mathrm{kJ} / \mathrm{kg}$ EBW0.75) & $\begin{array}{c}\text { Requirement } \\
\mathrm{ME}_{\mathrm{m}}\left(\mathrm{kJ} / \mathrm{kg} \mathrm{BW} \mathrm{BW}^{0.75}\right)\end{array}$ & $\mathrm{NE}_{\mathrm{m}}(\mathrm{kJ} / \mathrm{kg}$ EBW0.75) & $\mathrm{NE}_{\mathrm{m}}(\mathrm{kJ} / \mathrm{kg} \mathrm{BW} 0.75)$ & Reference \\
\hline \multicolumn{7}{|l|}{ Females: } \\
\hline $\begin{array}{l}\mathrm{Pb} \text { growing ewes and } \\
\text { at early pregnancy }\end{array}$ & - & - & 327 & - & - & (32) \\
\hline $\mathrm{Pb}$ adults ewes & 1.19 & 606 & 510 & - & - & (31) \\
\hline Mean & 1.19 & 606 & 419 & - & - & \\
\hline Minimum value & - & - & 327 & - & - & \\
\hline Maximum value & - & - & 510 & - & - & \\
\hline Standard deviation & - & - & 129 & - & - & \\
\hline $\mathrm{CV}, \%$ & - & - & 30.9 & - & - & \\
\hline \multicolumn{7}{|l|}{ Males: } \\
\hline Growing $\mathrm{Pb}$ & - & - & 490 & - & - & (3) \\
\hline Growing SI castrated & 1.18 & - & 465 & - & 308 & (4) \\
\hline Growing MN & 1.27 & 328 & 258 & 220 & & (8) \\
\hline Growing $\mathrm{Pb}$ & - & - & 598 & - & - & (32) \\
\hline Growing SI & 1.24 & 365 & 294 & 257 & - & (18) \\
\hline Growing SI castrated & - & - & 470 & & 310 & $(7)$ \\
\hline MN & - & - & 270 & 219 & - & (34) \\
\hline SI growing males & - & 329 & 267 & - & - & (20) \\
\hline 1/2 Do × 1/2 SI & - & - & 471 & - & 300 & (30) \\
\hline BS lambs & 1.23 & 363 & 295 & 240 & - & (26) \\
\hline Mean & 1.23 & 343 & 388 & 234 & 306 & \\
\hline Minimum value & 1.18 & 328 & 258 & 219 & 300 & \\
\hline Maximum value & 1.27 & 365 & 598 & 257 & 310 & \\
\hline Standard deviation & 0.04 & 19.0 & 123 & 18.34 & 5.3 & \\
\hline $\mathrm{CV}, \%$ & 3.04 & 5.53 & 31.78 & 7.84 & 1.73 & \\
\hline
\end{tabular}

$\mathrm{Pb}=$ Pelibuey; Ra= Rambouillet; SI= Santa Inês; MN= Morada Nova; Do= Dorper; BS= Brazilian Somali.

$\mathrm{CV}=$ Coeficient of variation. 
bioquímicas a nivel celular(29). La eficiencia de utilización de la energía de los alimentos tiene un impacto económico, y la mejor manera de determinarla es por medio de la eficiencia de la conversión alimenticia(27,30).

El Cuadro 3 muestra las estimaciones de requerimientos de EM y EN (EMm y ENm respectivamente) y el Cuadro 4 muestra las eficiencias de utilización de EM para mantenimiento $\left(K_{m}\right)$ en ovejas de pelo de diferentes razas en condiciones tropicales de América Latina. Es importante señalar que para el caso de las ovejas, en la presente revisión sólo se encontraron dos experimentos que estaban relacionados con esta información $(31,32)$ y la media ( \pm desviación estándar) de EMm fue $419 \pm 129$ kJ/kg PC0.75; esta información debe tomarse con reserva, ya que proviene de un número reducido de observaciones. En este sentido, Chávez et al(33), encontraron que suministrando $506 \mathrm{PC} 0.75 \mathrm{~kJ} / \mathrm{kg}$ para ovejas Pelibuey durante los primeros 100 días de gestación y $700 \mathrm{~kJ} / \mathrm{kg}$ PC 0.75 durante los últimos 50 días de gestación era suficiente para que las ovejas aumentaran de peso (36 g/día aproximadamente). Junto con esto, informaron que para la lactancia, el suministro de 1,000 $\mathrm{kJ} / \mathrm{kg}$ PC 0.75 fue suficiente para que las ovejas obtuvieran 4 a $20 \mathrm{~g} /$ día, producción de 700 a $800 \mathrm{ml}$ de leche y ser capaces de sostener un aumento de peso en sus corderos de 200 g/día.

Para machos en crecimiento, se utilizaron datos de nueve experimentos que involucraban las razas Pelibuey $(3,32)$, Santa Inês $(4,18,20)$, Morada Nova(8,34), 1/2 Dorper $\times 1 / 2$ Santa Inês(30) y Somalí Brasileño(26). El valor medio encontrado en el presente experimento para EMm fue 388 $\pm 123 \mathrm{~kJ} / \mathrm{kg}$ PC 0.75 ; sin embargo, estos datos mostraron un relativamente alto coeficiente de variación de $31.8 \%$, el cual puede atribuirse a diferencias entre experimentos, genotipos y cruces, entre otros factores.

En varios experimentos $(8,20,22,26,34)$ los valores de $\mathrm{EMm}(\mathrm{kJ} / \mathrm{kg} \mathrm{PC} 0.75)$ se derivan de la relación this information $(31,32)$ and the mean value ( \pm standard deviation) for $\mathrm{ME}_{\mathrm{m}}$ was $419 \pm 129$ $\mathrm{kJ} / \mathrm{kg} B W 0.75$. This information must be taken with reserve since it comes from a reduced number of observations. In this sense, Chávez et $\mathrm{a}(33)$, found that supplying $506 \mathrm{~kJ} / \mathrm{kg} \mathrm{BW} 0.75$ to Pelibuey ewes during the first $100 \mathrm{~d}$ of pregnancy and $700 \mathrm{~kJ} / \mathrm{kg}$ BW 0.75 during the last $50 \mathrm{~d}$ of pregnancy was enough for the ewes to gain weight (36 g/d approximately). Along with this, they reported that for lactation, the supply of $1,000 \mathrm{~kJ} / \mathrm{kg} \mathrm{BW} 0.75$ was enough for the ewes to gain 4 to $20 \mathrm{~g} / \mathrm{d}$, producing 700 to $800 \mathrm{ml}$ of milk and be able to sustain a weight gain by their lambs of $200 \mathrm{~g} / \mathrm{d}$.

For growing male sheep, data from nine experiments were used which involved Pelibuey $(3,32)$, Santa Inês $(4,18,20)$, Morada Nova(8,34), 1/2 Dorper $\times 1 / 2$ Santa Inês(30) and Brazilian Somali lambs(26). The mean value found in the present experiment for $M_{m}$ was $388 \pm 123 \mathrm{~kJ} / \mathrm{kg}$ BW0.75; however, this data showed a relatively high coefficient of variation of $31.8 \%$, this variation can be attributed to differences between experiments, genotypes, and crosses, among several other factors.

In several experiments $(8,20,22,26,34)$ the values for $M E_{m}(k J / k g ~ B W 0.75)$ were derived from the relation of BW/EBW and using the $k_{m}$ reported by these authors. In relation to $\mathrm{ME}_{\mathrm{m}}$, in growing Santa Inês sheep, some authors $(4,20)$ report a mean value for $\mathrm{ME}_{\mathrm{m}}$ of $342( \pm 107) \mathrm{kJ} / \mathrm{kg}$ $\mathrm{BW} 0.75$. For Morada Nova sheep $(8,34)$ an average $\mathrm{ME}_{\mathrm{m}}$ of $264( \pm 8.23) \mathrm{kJ} / \mathrm{kg}$; for Pelibuey $(3,32)$, a mean value of $544( \pm 76.4) \mathrm{kJ} / \mathrm{kg}$. While others $(26,30)$ reported only values available for $1 / 2$ Dorper $\times 1 / 2$ Santa Inês and Brazilian Somali lambs (Table 3).

In relation to $k_{m}$, it was found an average value of $0.70(18)$. An average value of 0.67 was reported(8) when estimating $k_{m}$ in diets with forage proportions of 40,55 and $70(4,7,20)$; in Santa Inês growing males reported a $k_{m}$ value of 0.66 . Recently(30) it was found a $k_{m}$ of 0.63 in $1 / 2$ Dorper $\times 1 / 2$ Santa Inês lambs. The 
entre PC/PCV y usando el $K_{m}$ reportado por estos autores. En relación con el EMm, en ovejas Santa Inês en crecimiento, algunos autores $(4,20)$ informan un valor medio de EMm de $342( \pm 107) \mathrm{kJ} / \mathrm{kg}$, y para Morada Nova $264( \pm 8.23) \mathrm{kJ} / \mathrm{kg}(8,34)$. En el caso de Pelibuey $(3,32)$, un valor medio de $544( \pm 76.4)$ $\mathrm{kJ} / \mathrm{kg}$. Mientras que otros autores $(26,30)$ informan sólo valores disponibles para corderos $1 / 2$ Dorper $\times 1 / 2$ Santa Inês y Somalí Brasileño (Cuadro 3).

En relación con $K_{m}$, se encontró un valor promedio de $0.70(18)$. Un valor promedio de 0.67 fue reportado(8) cuando $K_{m}$ se estimó en dietas con proporciones de forraje de 40,55 y $70 \%(4,7,20)$; en machos en crecimiento Santa Inês se registró un valor de 0.66 . Recientemente(30) se encontró un $K_{m}$ de 0.63 en corderos $1 / 2$ Dorper x 1/2 Santa Inês. El valor medio de $K_{m}$ en la presente revisión fue de 0.66. En este respecto, cuando la EM de las dietas de calidad media (como los utilizados en los trópicos) se utiliza con una baja eficiencia para mantenimiento y ganancia, $K_{m}$ es relativamente mayor en comparación con $K_{\mathrm{g}}(29)$. Además, este autor reportó que $K_{m}$ podría considerarse en promedio como 0.60 independientemente de la dieta; esto se aproxima al valor promedio de este trabajo, que fue de 0.66 (Cuadro 4).

La falta de información es más evidente para el caso de las ovejas, ya que existen muy pocos informes sobre la determinación de las necesidades energéticas en sus diferentes etapas fisiológicas (mantenimiento, gestación, lactancia), siendo estos componentes fundamentales de los sistemas de producción. Además, se sabe que la alimentación de las ovejas antes y después de parto tiene un efecto sobre la supervivencia y crecimiento de las crías. Por lo tanto, es necesario continuar con los trabajos que se centren en la determinación de las necesidades de nutrientes de ovinos de pelo y desarrollar un sistema de alimentación basado en las características de la ración, raza y condiciones ambientales que prevalecen en los mean value for $k_{m}$ in the present review was 0.66 . In this respect, even when ME of diets of medium quality (such as those commonly used in the tropics) is utilized with a low efficiency for maintenance and gain, $k_{m}$ is relatively higher compared to $k_{g}(29)$. Furthermore, this author reported that $k_{m}$ could be considered on average as 0.60 independently of the diet. This approximates to that found in this work, where an average $k_{m}$ value of 0.66 was obtained (Table 4).

Lack of information is more evident for the case of ewes, for which there are very few reports regarding determination of energy requirements in their different physiological stages (maintenance, pregnancy, lactation), being these fundamental components of the production systems. Furthermore, it is known that feeding of ewes before and after parturition has an effect on survival and growth of the offspring. It is thus necessary to continue with work focused on the determination of the nutrient requirements of hair sheep and develop a feeding system based on characteristics of the ration, breed and environmental conditions prevailing in Latin American tropics. Ration formulation with precise knowledge of the energy requirements of hair sheep and the concentration of ME (and its efficiency of utilization), of the feedstuffs available in the

Cuadro 4. Eficiencia de utilización de la EM para mantenimiento $\left(k_{m}\right)$ en ovinos de pelo

Table 4. Efficiency of utilization of ME for maintenance $\left(k_{m}\right)$ in hair sheep

\begin{tabular}{lcc}
\hline Breed or genotype & $k_{m}$ & Reference \\
\hline Morada Nova growing males & 0.67 & $(8)$ \\
Santa Inês growing males & 0.70 & $(18)$ \\
Santa Inês growing males & 0.66 & $(4)$ \\
Santa Inês castrated males, growing, grazing & 0.66 & $(7)$ \\
Santa Inês growing males & 0.66 & $(20)$ \\
$1 / 2$ Dorper x 1/2 Santa Inês & 0.63 & $(30)$ \\
Mean & 0.66 & \\
SD & 0.023 & \\
CV $(\%)$ & 3.39 & \\
\hline
\end{tabular}

$\mathrm{SD}=$ Standard deviation; $\mathrm{CV}=$ Coefficient of variation. 
trópicos de América Latina. La formulación de dietas con conocimiento preciso de las necesidades de energía de ovinos de pelo y la concentración de EM y la eficiencia de utilización, de los alimentos disponibles en los trópicos, tendrá una influencia en la mejora en la producción, dándole a los ovinos la cantidad exacta de alimento que requieren sin sobreestimar o subestimar sus necesidades ni el valor energético de los alimentos. La formulación basada en el conocimiento preciso de sus necesidades de mantenimiento y producción, contribuirá a reducir los costos de producción, ya que probablemente habría menor residuos (como el incremento de calor) derivados de la EM absorbida desde el tracto gastrointestinal. El conocimiento de las necesidades energéticas de las oveja de pelo para las diferentes etapas fisiológicas (mantenimiento, crecimiento, embarazo y lactancia), es de suma importancia, ya que estos podrían incorporarse fácilmente en los diferentes programas de formulación de dietas (CNSPS-S/SRNS), para satisfacer los requerimientos de energía de los ovinos de pelo, en condiciones tropicales.

Requerimientos de energía para ganancia de peso y $K_{m}$ estimado

El requerimiento de energía para crecimiento o ganancia de peso (EMg o ENg), corresponde al valor calórico o energía bruta de la proteína y grasa almacenadas en el cuerpo del animal(23). El ARC(23) menciona que la tasa de deposición de proteína afecta el crecimiento, que a su vez afecta los requerimientos de EN. La composición de la ganancia de peso, expresado como aumento de PCV (ganancia de PCV), es el principal factor determinante de las necesidades energéticas de ganancia de peso, que se estima de la energía retenida en el cuerpo(15). Por otra parte, el principal factor para la determinación de la composición de la ganancia en la etapa de madurez, en la que el animal está más cercano de su peso adulto, más grasa (y energía), es almacenamiento en la ganancia.

Ferrell y Oltjen(28) informaron que la dieta se utiliza con diferente eficiencia dependiendo del tipo de ración (ingredientes), nivel de consumo tropics, will have an influence on improvement in sheep production, by giving sheep the precise amount of feed that require without over or under estimating its requirements nor the energy value of feedstuffs. Ration formulation for sheep based on the precise knowledge of their requirement for maintenance and production, will contribute to reduce production costs, since there would probably be a lower waste (as heat increment) arising from ME absorbed from the GIT. Knowledge of energy requirements of hair sheep for the different physiological stages (maintenance, growth, pregnancy and lactation), is of paramount importance since these could be readily incorporated in different programs for ration formulation (CNSPS-S/SRNS) and with these, formulates rations that will satisfy the energy requirements of hair sheep kept under tropical conditions.

Energy requirements for weight gain and estimated $k_{g}$

The energy requirement for growth or weight gain $\left(\mathrm{ME}_{\mathrm{g}}\right.$ or $\left.\mathrm{NE}_{\mathrm{g}}\right)$, corresponds to the caloric value or gross energy of the protein and fat stored in the bodyl(23). The ARC(23) mentioned that rate of growth affects protein deposition which in turn affects NE requirements. Composition of weight gain, expressed as empty body weight (EBW), is the main determinant of energy requirements for weight gain, which is estimated from energy retained in the body(15). Moreover, the main factor determining the composition of gain in the mature stage, in which as the animal is closer to its adult weight, more fat (and energy) is stored in the gain.

Ferrell and Oltjen(28) reported that ME in the ration is used with different efficiencies depending on the type of ration (ingredients), level of intake and the physiological function for which it is being utilized by the animal. Tolkamp(29) reported that $k_{g}$ for rations of low to medium quality (such as those of tropical forages), is expected to be low. Tedeschi et al(35) mentioned that there are factors which may affect $k_{g}$, pointing out that ration (energy density 
y la función fisiológica en que está siendo utilizada por el animal. Tolkamp(29) informó que para raciones de baja a mediana calidad (como los de forrajes tropicales), se espera una $K_{g}$ baja. Tedeschi et al(35) mencionan que hay factores que pueden afectar $K_{g}$, señalando que la ración (densidad de energía y proporción molar de los ácidos grasos volátiles) y la composición de la ganancia de peso, son las cuestiones más importantes; estos autores concluyeron que el uso de una combinación de la composición química del cuerpo y la concentración de energía de la ración, puede ser un mejor enfoque para la evaluación de la eficiencia de la utilización de EM para el mantenimiento y crecimiento. Al respecto, algunos investigadores, demostraron que el factor principal que afecta $K_{q}$ es la composición de la ganancia en la PCV $(36,37)$; incluso cuando el nivel de EM interfiere con $K_{q}$, una ración con una alta concentración de EM inducirá un contenido alto de grasa en la ganancia.

En otros trabajos $(36,37)$ estos autores no encontraron evidencia genética de requerimientos de EN para ganancia de peso, concluyendo que el efecto de la raza o genotipo en EN para ganancia puede ser atribuido a los diferentes pesos a la madurez, y a la precocidad en la deposición de grasa en las distintas razas de ganado. Diferentes pesos a la madurez de las razas, pueden determinar diferentes grados de madurez en los animales con el mismo peso absoluto y la misma tasa de ganancia; en la ganancia de peso de los animales de razas con bajo peso a la madurez en comparación con las razas de madurez tardía se esperan altas concentraciones de energía. En la presente revisión, trabajos con corderos Morada Nova $(8,21)$ estiman valores de ganancia de 13.8 a $17.9 \mathrm{~kJ} \mathrm{EN} / \mathrm{g}$ y 7.0 a $9.2 \mathrm{~kJ} \mathrm{EN/g}$, en animales de peso comprendido entre 15 y $30 \mathrm{~kg}$, respectivamente. Regadas-Filho et al(22) en corderos machos Santa Inês en crecimiento, reportaron de 10.0 a $14.5 \mathrm{~kJ} \mathrm{EN} / \mathrm{g}$ en animales entre 15 y $30 \mathrm{~kg}$. Sin embargo, con este mismo tipo de animales, se encontraron valores de 6.0

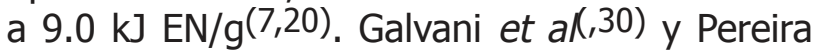

and volatile fatty acids molar proportions) and the composition of the weight gain are the most important issues; these authors concluded that the use of a combination of chemical composition of the body and energy concentration of the ration may be a better approach for the assessment of efficiency of utilization of ME for maintenance and growth. Indeed, some authors $(36,37)$ demonstrated that the main factor affecting $k_{g}$ is the composition of gain in the EBW; even when the level of ME interferes with $k_{g}$, a ration with a high ME concentration, will induce a high fat content in the gain, therefore, the effect of the energy content of the ration is considered in the composition of the gain.

On the other hand $(36,37)$ these same authors did not find evidence of genetic background on $\mathrm{NE}$ requirements for weight gain, concluding that the effect of breed or genotype on NE for gain can be attributed to the different mature weights and to the precocity of fat deposition in the different breeds of cattle. Different mature weights of breeds, may determine different degrees of maturity in animals with the same absolute weight and the same rate of gain, high energy concentrations are expected in the gain of animals of breeds with low weight at maturity compared to that of late maturity breeds. In the present review, works with Morada Nova $\operatorname{lambs}(8,21)$ estimated values of 13.8 to $17.9 \mathrm{~kJ} \mathrm{NE} / \mathrm{g}$ gain and 7.0 to $9.2 \mathrm{~kJ}$ $\mathrm{NE} / \mathrm{g}$ gain respectively, in animals weighing from 15 to $30 \mathrm{~kg}$. Regadas-Filho et a(22) in Santa Inês growing male lambs reported values of 10.0 to $14.5 \mathrm{~kJ} \mathrm{NE} / \mathrm{g}$ gain in animals between 15 and $30 \mathrm{~kg}$. Nonetheless, in Santa Inês growing male lambs found values of 6.0 to 9.0 kJ NE/g gain $(7,20)$. Galvani et a( $(30)$ and Pereira et $a(26)$ reported values of 9.3 to 14.7 and 9.2 to $11 \mathrm{~kJ} \mathrm{NE} / \mathrm{g}$ gain in $1 / 2$ Dorper $\times 1 / 2$ Santa Inês and Brazilian Somali lambs, respectively. Using the values described above, it was found a mean value of 8.75 to $14.06 \mathrm{~kJ} \mathrm{NE} / \mathrm{g}$ gain in hair sheep of different breeds under tropical conditions of Latin America. Table 5 shows NE requirements for daily weight gain (MJ/animal/d) 
Cuadro 5. Requerimientos de EN para ganancia de peso (MJ/animal/d) en ovinos Santa Inés, Morada Nova, 1/2 Dorper $\times 1 / 2$ Santa Inês y Somalí Brasileño con pesos entre 15 y $45 \mathrm{~kg}$

Table 5. NE requirements for weight gain (MJ/sheep/d) of Santa Inés, Morada Nova, 1/2 Dorper $\times$ 1/2 Santa Inês and Brazilian Somali hair heep weighing between 15 and $45 \mathrm{~kg}$

\begin{tabular}{|c|c|c|c|c|c|c|c|c|c|c|c|}
\hline \multirow{2}{*}{$\begin{array}{l}\text { BW } \\
(\mathrm{kg})\end{array}$} & \multirow{2}{*}{$\begin{array}{l}A D G \\
(g / d)\end{array}$} & \multicolumn{7}{|c|}{ Reference } & \multirow[b]{2}{*}{ Mean } & \multirow[b]{2}{*}{ SD } & \multirow[b]{2}{*}{$\mathrm{CV}$} \\
\hline & & (8) & (7) & (18) & (34) & (20) & (30) & (26) & & & \\
\hline \multirow[t]{5}{*}{15} & 100 & 1.38 & 0.65 & 1.00 & 0.71 & 0.69 & 0.94 & 0.93 & 0.90 & 0.25 & 28.2 \\
\hline & 150 & 2.08 & 0.97 & 1.49 & 1.05 & 1.04 & 1.41 & 1.39 & 1.35 & 0.42 & 31.1 \\
\hline & 200 & 2.76 & 1.30 & 1.99 & 1.42 & 1.04 & 1.88 & 1.85 & 1.75 & 0.62 & 35.4 \\
\hline & 250 & - & & 2.49 & 1.76 & 1.73 & 2.35 & 2.31 & 2.13 & 0.40 & 18.6 \\
\hline & 300 & - & & & 2.09 & & 2.82 & 2.78 & 2.56 & 0.51 & 20.1 \\
\hline \multirow[t]{5}{*}{20} & 100 & 1.60 & 0.86 & 1.16 & 0.79 & 0.77 & 1.05 & 1.00 & 1.03 & 0.32 & 30.6 \\
\hline & 150 & 2.40 & 1.29 & 1.74 & 1.17 & 1.15 & 1.57 & 1.51 & 1.55 & 0.48 & 30.8 \\
\hline & 200 & 3.21 & 1.72 & 2.33 & 1.59 & 1.53 & 2.09 & 2.01 & 2.07 & 0.63 & 30.6 \\
\hline & 250 & - & & 2.91 & 1.97 & 1.91 & 2.62 & 2.51 & 2.38 & 0.49 & 20.6 \\
\hline & 300 & - & & & 2.34 & & 3.14 & 3.01 & 2.83 & 0.56 & 19.9 \\
\hline \multirow[t]{5}{*}{25} & 100 & 1.79 & 1.05 & 1.31 & 0.84 & 0.82 & 1.13 & 1.07 & 1.15 & 0.36 & 31.6 \\
\hline & 150 & 2.69 & 1.58 & 1.97 & 1.30 & 1.23 & 1.70 & 1.60 & 1.72 & 0.53 & 31.0 \\
\hline & 200 & 3.58 & 2.11 & 2.62 & 1.72 & 1.64 & 2.27 & 2.13 & 2.30 & 0.71 & 31.1 \\
\hline & 250 & - & & 3.28 & 2.13 & 1.64 & 2.84 & 2.67 & 2.51 & 0.73 & 28.9 \\
\hline & 300 & - & & & 2.55 & & 3.41 & 3.00 & 2.99 & 0.60 & 20.2 \\
\hline \multirow[t]{5}{*}{30} & 100 & - & 2.11 & 1.45 & 0.92 & 0.87 & 1.21 & 1.10 & 1.28 & 0.50 & 39.4 \\
\hline & 150 & - & 1.85 & 2.17 & 1.38 & 1.30 & 1.82 & 1.65 & 1.70 & 0.36 & 21.3 \\
\hline & 200 & - & 2.47 & 2.90 & 1.80 & 1.74 & 2.43 & 2.20 & 2.26 & 0.49 & 21.8 \\
\hline & 250 & - & & 3.62 & 2.26 & 2.17 & 3.03 & 2.75 & 2.77 & 0.69 & 24.8 \\
\hline & 300 & - & & - & 2.72 & & 3.64 & 3.30 & 3.22 & 0.65 & 20.2 \\
\hline \multirow[t]{5}{*}{35} & 100 & - & & - & & & 1.28 & & 1.28 & & \\
\hline & 150 & - & & - & & & 1.92 & & 1.92 & & \\
\hline & 200 & - & & - & & & 2.57 & & 2.57 & & - \\
\hline & 250 & - & & - & & & 3.21 & & 3.21 & & - \\
\hline & 300 & - & & - & & & 3.85 & & 3.85 & & - \\
\hline \multirow[t]{5}{*}{40} & 100 & - & & - & & & 1.35 & & 1.35 & & - \\
\hline & 150 & & & - & & & 2.02 & & 2.02 & & - \\
\hline & 200 & - & & & & & 2.69 & & 2.69 & & - \\
\hline & 250 & - & & - & & & 3.37 & & 3.37 & & - \\
\hline & 300 & - & & & & & 4.05 & & 4.05 & & - \\
\hline \multirow[t]{5}{*}{45} & 100 & - & & - & & & 1.41 & & 1.41 & & - \\
\hline & 150 & - & & - & & & 2.11 & & 2.11 & & - \\
\hline & 200 & - & & - & & & 2.81 & & 2.81 & & \\
\hline & 250 & - & & - & & & 3.52 & & 3.52 & & \\
\hline & 300 & - & & - & & & 4.22 & & 4.22 & & - \\
\hline
\end{tabular}

$\mathrm{BW}=$ Body weight; $\mathrm{ADG}=$ Average daily gain; $\mathrm{SD}=\mathrm{Standard}$ deviation; $\mathrm{CV}=$ Coefficient of variation.

et a(26) informaron de 9.3 a 14,7 y 9.2 a 11 $\mathrm{kJ}$ EN/g para ganancia en corderos $1 / 2$ Dorper $x$ $1 / 2$ Santa Inês y Somalí Brasileño, respectivamente. Utilizando los valores descritos anteriormente, se encontró un valor promedio de 8.75 a $14.06 \mathrm{~kJ}$ EN/g para ganancia en ovinos de pelo de diferentes razas en condiciones tropicales de América Latina. El Cuadro 5 muestra los requisitos de EN para of hair sheep according to live weight and expected weight gain.

As regard to the efficiency of ME utilization for growth, it has been reported that in growing Pelibuey sheep, this value varies according to age and weight, being higher during the first stages of growth and decreasing as the animal approaches mature weight, due to a greater 
ganancia de peso (MJ/animal/día) de ovinos de pelo según su peso vivo y ganancia de peso esperada.

Con respecto a la eficiencia de la utilización de EM para el crecimiento $\left(K_{g}\right)$, se ha informado que en ovinos Pelibuey, este valor varía según la edad y peso, siendo mayor durante las primeras etapas de crecimiento y disminuyendo a medida que el animal se acerca a su peso maduro, debido a una mayor deposición de grasa en los tejidos del cuerpo(32). Sin embargo, estos autores también sugirieron que la mayor demanda puede ser debida al mayor requerimiento de energía por unidad de peso. El Cuadro 6 muestra las estimaciones de $K_{g}$ en ovinos de pelo. La $K_{g}$ reportada para ovinos de pelo osciló entre $0.38(8)$ y $0.48(38)$, y el promedio obtenido con el propósito de esta revisión fue $0.42 \pm 0.04$.

Con base en los datos obtenidos en esta revisión, respecto a las necesidades de energía para ganancia de peso (MJ EN/animal/día) y $K_{g}$ $(0.42)$, se encontró que los requerimientos de energía para la ganancia de peso $(\mathrm{kJ} \mathrm{EM} / \mathrm{g})$ oscilaron entre 20.8 y 33.5 (media: 27.7); Asimismo, se informó que los valores medios para las necesidades de energía para ganancia (MJ EM/animal/d) derivados, fueron superiores en un $26 \%$ a los reportados previamente para ovinos Pelibuey en crecimiento(39), sin embargo, es importante destacar que los datos del presente trabajo, y de otros(39), fueron cercanos, con ganancias de $100 \mathrm{~g}$ (5 \% más en promedio), en comparación con mayores tasas de ganancia.

Requerimientos de energía para ovinos en pastoreo

En las regiones tropicales, los sistemas de producción ovina generalmente son mixtos, donde en la mayoría de los casos, los animales (ovejas principalmente) se mantienen en pastoreo con o sin alimentación suplementaria. La alimentación se basa en el uso de gramíneas nativas e introducidas y arbustos; las fat deposition in body tissues(32). However, those authors also suggested that the greater demand may be due to the higher requirement of energy per unit weight gain. Table 6 shows estimations of $k_{g}$ in hair sheep. The $k_{g}$ reported for hair sheep ranged from $0.38(8)$ to $0.48(38)$. The average $k_{g}$ value obtained for the purpose of this review was $0.42 \pm 0.04$.

Based on the data obtained in this review regarding the energy requirement of weight gain (MJ NE/animal/d) and $k_{g}(0.42)$, it was found that the energy requirements for weight gain ( $\mathrm{kJ} \mathrm{ME} / \mathrm{g}$ gain) ranged from 20.8 to 33.5 (mean: 27.7). Similarly, it was reported that the mean values for the energy requirements for gain (MJ ME/animal/d) derived, were higher by $26 \%$ than those previously reported for growing Pelibuey sheep(39), nonetheless, it is important to emphasize that the data of the present review and from others(39), average daily gain were closer of $100 \mathrm{~g}$ (5 \% higher on average), compared to higher rates of gain.

\section{Energy requirements of grazing sheep}

In tropical regions, sheep production systems are usually mixed, where in most cases, animals (ewes mainly) are maintained grazing with or without supplementary feed. Feeding is based on the use of native and introduced grasses and shrubs; sheep farms have low production

Cuadro 6. Eficiencia de utilización de la EM para ganancia de peso $\left(k_{g}\right)$ en ovinos de pelo

Table 6. Efficiency of utilization of ME for weight gain $\left(k_{g}\right)$ in hair sheep

\begin{tabular}{lcc}
\hline Breed or genotype & $k_{g}$ & Reference \\
\hline Santa Inês males & 0.43 & $(18)$ \\
Morada Nova, sheep & 0.38 & $(8)$ \\
Santa Inés growing males & 0.48 & $(20)$ \\
$1 / 2$ Dorper x 1/2 Santa Inês & 0.39 & $(30)$ \\
Mean & 0.42 & \\
SD & 0.044 & \\
CV $(\%)$ & 10.82 & \\
\hline
\end{tabular}

$\mathrm{SD}=$ Standard deviation; $\mathrm{CV}=$ Coefficient of variation. 
explotaciones ovinas tienen bajos parámetros de producción y rentabilidad y baja tasa de adopción de nuevas tecnologías. Por esa razón es primordial la estimación de los requerimientos nutricionales de ovinos en pastoreo; sin embargo, hay pocos reportes de experimentos donde se hayan determinado. En este contexto, se menciona(40), con corderos destetados Rambouillet x Pelibuey de $13.5 \mathrm{~kg}$ en pastoreo de Buffel (Cenchrus ciliaris), un requerimiento de energía para mantenimiento de $359 \mathrm{~kJ} \mathrm{EM} / \mathrm{kg}$ $\mathrm{PC} 0.75 /$ día. En otro trabajo(7) considerando un $K_{m}$ de 0.66, informaron una EMm de $470 \mathrm{~kJ}$ $\mathrm{EM}$, por lo tanto $\mathrm{ENm}$ fue $310 \mathrm{~kJ} / \mathrm{kg} \mathrm{PC} 0.75$. Asimismo, encontraron que en corderos de 3 a 4 meses de edad (machos castrados) de la raza Santa Inês de 15 a $30 \mathrm{~kg}$ de peso en pastoreo de buffel tenían un requerimiento de $18.2 \mathrm{~kJ} \mathrm{EM} / \mathrm{g}$ para ganancia de peso en corderos de $15 \mathrm{~kg}$. En corderos de $20 \mathrm{~kg}$, el requerimiento fue $24 \mathrm{~kJ}$, en corderos de $25 \mathrm{~kg}$ el requerimiento fue $30 \mathrm{~kJ}$ y en los animales de $30 \mathrm{~kg}$ de $35 \mathrm{~kJ}$. El valor estimado para $K_{g}$ fue 0.42 al evaluar todos los pesos.

\section{Peso corporal vacío (PCV)}

Marcondes et al(36) sugirieron que el primer paso en la determinación de las necesidades energéticas de los rumiantes es la conversión de $P C$ encogido (PCE, con ayuno de 16 a 24 h) a PCV. También se ha informado(30), que la concentración de energía en el cuerpo generalmente ha sido expresada como una función de PCV en lugar de PCE, debido a que la interferencia del contenido gastrointestinal es eliminada completamente. EI PCV es equivalente a PCE menos el peso del contenido gastrointestinal. Según algunos autores $(12,16,30)$, el PCE se define como el $96 \%$ de PC lleno $(\mathrm{kg})$ y definen PCV como: $P C V=0.85 \times$ PCE $(\mathrm{kg})$.

Sin embargo, para determinar el PCV, los animales tienen que ser sacrificados; por esta razón, han desarrollado ecuaciones de regresión para estimar PCV a partir del PC O PCE, e incluir esta información, y así contribuir a la actualización con los datos para la estimación and profitability parameters and low rate of adoption of new technologies. For that reason estimation of nutrient requirement of grazing sheep must be of paramount importance. However, there are few reports of experiments where nutrient requirements of grazing sheep have been determined. In this context $(40)$, with Rambouillet $\times$ Pelibuey sheep recently weaned of $13.5 \mathrm{~kg}$ grazing Buffel (Cenchrus ciliaris) grass, found an energy requirement for maintenance of $359 \mathrm{~kJ} \mathrm{ME} / \mathrm{kg} \mathrm{BW} 0.75 / \mathrm{d}$. On the other hand(7) considering a $k_{m}$ of 0.66 , reported a $\mathrm{ME}_{\mathrm{m}}$ of $470 \mathrm{~kJ} \mathrm{ME} / \mathrm{kg}$, therefore $\mathrm{NE}_{\mathrm{m}}$ was $310 \mathrm{~kJ} / \mathrm{kg} \mathrm{BW0.75}$. Similarly, reported that in lambs of 3 to 4 mo old (castrated males) of the Santa Inês breed of 15 to $30 \mathrm{~kg}$ live weight grazing buffel grass had a requirement of $18.2 \mathrm{~kJ} \mathrm{ME} / \mathrm{g}$ weight gain in lambs of $15 \mathrm{~kg}$. In lambs of $20 \mathrm{~kg}$, the requirement was $24 \mathrm{~kJ}$, in lambs of $25 \mathrm{~kg}$ the requirement was $30 \mathrm{~kJ}$ and in animals of $30 \mathrm{~kg}$ it was $35 \mathrm{~kJ}$. The estimated $k_{g}$ value was 0.42 for all weights evaluated.

\section{Empty body weight (EBW)}

Marcondes et a(36) suggested that the first step in the determination of energy requirements of ruminants is the conversion of shrunk BW (SBW) to EBW. Also, some authors mention(30), that the energy concentration in the body has usually been expressed as a function of EBW rather than SBW because interference by the gastrointestinal content is completely eliminated. The EBW is equivalent to SBW minus the weight of the gastrointestinal contents. SBW is also defined as $96 \%$ of full BW $(\mathrm{kg})$ and defines EBW as: $\mathrm{EBW}=0.85 \times \mathrm{SBW}(\mathrm{kg})(12,16,30)$.

Nonetheless, to determine the EBW, sheep have to be slaughtered; for this reason, regression equations have been developed to estimate EBW from BW or SBW and include this information and thus contribute to updating with the data for estimation of some parameters required by nutritional models such as SRNS in order to predict the performance of hair sheep breeds(11,32). 
de algunos parámetros requeridos por los modelos nutricionales como SRNS para predecir el desempeño de razas de ovejas de pelo $(11,32)$.

Basados en datos reportados en la literatura $(8,22,26,30,34,38)$, se ajustó una ecuación de regresión lineal.

(Ecuación 1): PCV $=-1.80( \pm 0.59 * * *)+0.89$ $( \pm 0.02 * * *) \times$ PCE $(\mathrm{R} 2=0.98 ; \mathrm{MSE}=1.669$; $\mathrm{RSD}=1.292 ; P<0.0001 ; \mathrm{n}=51)$.

Se encontró que el contenido gastrointestinal fue $10 \%$ y la PCV $90 \%$ del PC en animales machos. Los valores encontrados en el presente trabajo en cuanto a PC correspondiente a PCV fueron superiores a los reportados en la literatura $(16,32)$. También se encontró que la relación $\mathrm{PC} / \mathrm{PCV}$ fue en promedio de 1.23 para los machos.

Con respecto a las hembras, en ovejas Pelibuey adultas en diferentes estados fisiológicos, el peso del contenido gastrointestinal fue aproximadamente un $19 \%$ de PCE(11). Recientemente, (Chay-Canul, datos inéditos) utilizando datos de 28 ovejas Pelibuey adultas con diferentes pesos y condicion corporal, se conformó la siguiente ecuación:

(Ecuación 2): $\mathrm{PCV}=-3.82( \pm 0.93 * * *)+0.92$ $( \pm 0.02 * * *) \times \mathrm{PCE}(\mathrm{R} 2=0.96, \mathrm{MSE}=2.183$, $\mathrm{RSD}=1.477, P<0.0001 ; \mathrm{n}=71)$.

La PCV correspondió al $92 \%$ de PC. Por otra parte, la relación PC/PCV fue en promedio 1.22 para ovejas.

Composición corporal y su relación con los requerimientos de energía

Para estimar las necesidades de nutrientes es importante saber el aumento de peso y la composición corporal, porque estos están directamente relacionados. Fernandes et al(41) afirman que el conocimiento de la composición corporal de los animales es de gran relevancia en estudios de nutrición animal para determinar necesidades de nutrientes. Costa et a/(21) y
Based on data reported $(8,22,26,30,34,38)$, a linear regression equation was fitted.

(Equation 1): $\mathrm{EBW}=-1.80( \pm 0.59 * * *)+0.89$ $( \pm 0.02 * * *) \times \mathrm{SBW}\left(\mathrm{R}^{2}=0.98 ; \mathrm{MSE}=1.669\right.$; $\mathrm{RSD}=1.292 ; P<0.0001 ; \mathrm{n}=51)$.

It was found that gastrointestinal fill was $10 \%$ and the EBW was $90 \%$ of BW in male animals. The values found in the present work as regard to BW corresponding to EBW were higher to those reported in the literature $(16,32)$. Also it was found that the relation BW/EBW was on average 1.23 for males.

Regarding females, in adult Pelibuey ewes at different physiological stages the weight of the gastrointestinal content was approximately $19 \%$ of SBW(11). Recently, (Chay-Canul, unpublished data) used a data set of 28 adult Pelibuey ewes with different BW and body condition score and when analyzed, the data conformed an equation:

(Equation 2): $\mathrm{EBW}=-3.82( \pm 0.93 * * *)+0.92$ $( \pm 0.02 * * *) \times \mathrm{SBW}\left(\mathrm{R}^{2}=0.96, \mathrm{MSE}=2.183\right.$, $\mathrm{RSD}=1.477, \quad P<0.0001 ; \mathrm{n}=71)$.

The EBW corresponded to $92 \%$ of BW. Moreover, the relation BW/EBW was on average 1.22 for ewes.

Body composition and its relationship with energy requirements

In order to estimate nutrient requirements it is important to know body composition and weight gain of sheep because these are directly related. Fernandes et a(41) suggested that knowledge of body composition of the animals is of great relevance in studies of animal nutrition to determine nutrient requirements. Costa et al(21) and Maia et a/(19) reported that the first step for determining nutritional requirements is to measure the body composition of the sheep, which may be obtained by direct or indirect methods. Although the direct determination of body composition by grinding and analyzing all body tissues is the most reliable method, it is expensive, time consuming, and laborious. 
Maia et a(19) informan que el primer paso para la determinación de los requerimientos nutricionales es medir la composición corporal de los ovinos, que puede obtenerse por métodos directos o indirectos. Aunque la determinación directa de la composición corporal por molienda y análisis de todos los tejidos del cuerpo es el método más confiable, es caro, lento y laborioso.

La composición corporal de los ovinos es un factor importante para determinar los requerimientos nutricionales, ya que el cuerpo se compone básicamente de agua, proteína, grasa y minerales, en proporciones que varían según la raza, edad, tasa de crecimiento, el género y nutrición, entre otros(34).

En corderos Morada Nova de 15.23 a $25.43 \mathrm{~kg}$ se reportó que la composición corporal (\% PCV) varió de 70.14 a $64.61 \%$ agua, 18.14 a $18.17 \%$ de proteína cruda, de 6.7 a $12.1 \%$ grasa y 7.28 a $9.50 \mathrm{MJ} / \mathrm{kg} \mathrm{PCV}(8)$. Los autores informaron también que la concentración de proteína bruta se redujo de 181.76 a 178.74 $\mathrm{g} / \mathrm{kg}$ PCV cuando el PC de los animales aumentó de 15 a $25 \mathrm{~kg}$. Asimismo, otros autores(34), informaron que el contenido de energía y grasa en el PCV aumentó de $79.38 \mathrm{~g} / \mathrm{kg}$ PCV, a 8.83 $\mathrm{MJ} / \mathrm{kg} ， 6.86 \mathrm{MJ} / \mathrm{kg}$ y $123,73 \mathrm{~g} / \mathrm{kg}$ ， respectivamente, conforme el PV de los animales aumentó de 15 a 30 kg; también se observó un efecto cuadrático para las concentraciones de agua y grasa con el aumento de PCV, y el porcentaje de proteínas mostró una tendencia a disminuir linealmente, presentando una disminución de 0.10 puntos porcentuales por cada kilo de incremento de PCV.

En corderos Santa Inês(22), se encontró que el contenido de energía y grasa del PCV aumentó de $7.99 \mathrm{MJ} / \mathrm{kg}$ y $85.16 \mathrm{~g} / \mathrm{kg}$ de $P C V$, respectivamente, a $11.63 \mathrm{MJ} / \mathrm{kg}$ y $221.23 \mathrm{~g} / \mathrm{kg}$, conforme el PV aumentó de 15 a $30 \mathrm{~kg}$; también se observó un efecto cuadrático para las concentraciones de agua, grasa y energía con el aumento de PCV; mencionan que el porcentaje de proteína cruda mostró una tendencia a disminuir linealmente, de 0.12
Sheep body composition is an important factor when determining nutritional requirements, since the body is basically composed of water, protein, fat and minerals, in proportions that vary according to breed, age, rate of growth, sex and nutrition, among others(34).

In Morada Nova lambs weighing 15.23 to 25.43 $\mathrm{kg}$, reported that the body composition (\% EBW) varied from 70.14 to $64.61 \%$ water, 18.14 to $18.17 \%$ crude protein, 6.7 to $12.1 \%$ fat and 7.28 to $9.50 \mathrm{MJ} / \mathrm{kg}$ EBW(8). Those authors also reported that the concentration of crude protein was reduced from 181.76 to $178.74 \mathrm{~g} / \mathrm{kg}$ EBW when the BW of animals increased from 15 to $25 \mathrm{~kg}$. Others(34), informed that the energy and fat contents of the EBW increased from $6.86 \mathrm{MJ} / \mathrm{kg}$ and $79.38 \mathrm{~g} / \mathrm{kg}$ EBW, to $8.83 \mathrm{MJ} / \mathrm{kg}$ and $123.73 \mathrm{~g} / \mathrm{kg}$ of EBW, respectively, as the BW of the animals increased from 15 to $30 \mathrm{~kg}$; a quadratic effect was also observed for the concentrations of water and fat with increasing EBW and the percentage of protein showed a tendency to decrease linearly, representing a decrease of 0.10 percentage points for each kilogram increase in EBW.

In Santa Inês lambs(22), reported that the energy and fat contents of the EBW of the sheep increased from $7.99 \mathrm{MJ} / \mathrm{kg}$ and $85.16 \mathrm{~g} / \mathrm{kg}$ of EBW, respectively, to $11.63 \mathrm{MJ} / \mathrm{kg}$ and 221.23 $\mathrm{g} / \mathrm{kg}$, as the BW increased from 15 to $30 \mathrm{~kg}$; they also observed a quadratic effect for the concentrations of water, fat, and energy with increasing EBW and informed that the percentage of crude protein showed a tendency to decrease linearly, representing a decrease of 0.12 percentage points for each kilogram increase in EBW, from 15 to $30 \mathrm{~kg}$. Those authors, concluded that the net energy requirement for EBW gain increased with increasing body weight, due to a parallel increase in the quantity of fat deposited per kilogram gained. Correspondingly, some authors (38), found that the crude protein content of the body decreased but fat and energy body content increased as the EBW increased from 15 to $45 \mathrm{~kg}$. Similar results (7) mention that the 
puntos porcentuales por cada kilogramo de incremento de PCV, de 15 a $30 \mathrm{~kg}$. Los autores concluyeron que los requerimientos de energía neta para PCV aumentaron con el aumento de peso corporal, debido a un aumento paralelo en la cantidad de grasa depositada por kilogramo de ganancia. En consecuencia, algunos autores(38), mencionan que el contenido de proteína cruda del cuerpo disminuyó, pero el contenido de grasa y energía del cuerpo aumentaron conforme el PCV aumentó de 15 a $45 \mathrm{~kg}$. Resultados similares mencionan que los niveles de suplementación y valores PCV afectaron positivamente contenidos de MS en la PCV de $31.15,35.18$ y $36.19 \%(7)$. Sin embargo, el contenido de proteína cruda en la PCV disminuyó con la suplementación. Esto puede explicarse por la mayor ganancia de PC y los depósitos de grasa con el aumento en nivel de suplementación. El contenido de energía en el PCV varió de 6.23 a $8.66 \mathrm{MJ} / \mathrm{kg}$ PCV. La concentración de proteína cruda disminuyó de 212 a $180 \mathrm{~g} / \mathrm{kg}$ PCV cuando el PC aumentó de 15 a $30 \mathrm{~kg}$. El contenido de grasa en corderos de 15 a $30 \mathrm{~kg}$ osciló entre 17.3 y 103.2 g/ kg PCV. Estos autores concluyeron que el requisito de proteína disminuyó y el requerimiento de energía aumenta con el aumento de peso corporal.

Galvani et a/(30) encontraron que la concentración de grasa en la ganancia $(\mathrm{g} / \mathrm{kg}$ de ganancia del PCV), aumentó con el aumento en el PV de los corderos, y que la cantidad de proteína cruda en la ganancia no fue afectada por el peso al sacrificio. Pereira et a(26) con corderos Somalí Brasileño, informaron que la energía del animal y el contenido de grasa del PCV aumentaron de $11.20 \mathrm{MJ} / \mathrm{kg}$ y $208.54 \mathrm{~g} / \mathrm{kg}$ a $13.54 \mathrm{MJ} / \mathrm{kg}$ y $274.95 \mathrm{~g} / \mathrm{kg}$ de $\mathrm{PCV}$, respectivamente, conforme el PV aumentó de 13.0 a $28.70 \mathrm{~kg}$.

Con los datos obtenidos en la presente revisión, la composición corporal de ovinos de pelo se relacionó con el PCV y se ajustaron tres ecuaciones para predecir la composición corporal (Figura 1). Las ecuaciones ajustadas fueron: supplementation levels and EBW values affected positively DM content in the EBW from 31.15 to 35.18 and to $36.19 \%$. However, the crude protein content in the EBW decreased with supplementation $(P<0.05)$. This can be explained by the higher BW gain and fat deposition with the increase in supplementation level. The energy content in the EBW ranged from 6.23 to $8.66 \mathrm{MJ} / \mathrm{kg}$ EBW. The crude protein concentration decreased from 212 to $180 \mathrm{~g} / \mathrm{kg}$ EBW when the body weight increased from 15 to $30 \mathrm{~kg}$. The fat contents in 15 to $30 \mathrm{~kg} \mathrm{BW}$ lambs ranged from 17.3 to $103.2 \mathrm{~g} / \mathrm{kg}$ EBW. These authors concluded that the protein requirement decreased and the energy requirement increased with the increase in body weight.

Galvani et a/(30) found that fat concentration in the gain ( $\mathrm{g} / \mathrm{kg}$ EBW gain), increased with an increase in the BW of the lambs and that the amount of crude protein in the gain was not affected by slaughter weight. Pereira et al(26) with Brazilian Somali lambs, reported that the animal's energy and EBW fat contents increased

Figure 1. Composición corporal de ovinos de pelo machos como función del peso corporal vacío (EBW)

Figure 1. Body composition of male hair sheep as a function of empty body weight (EBW)

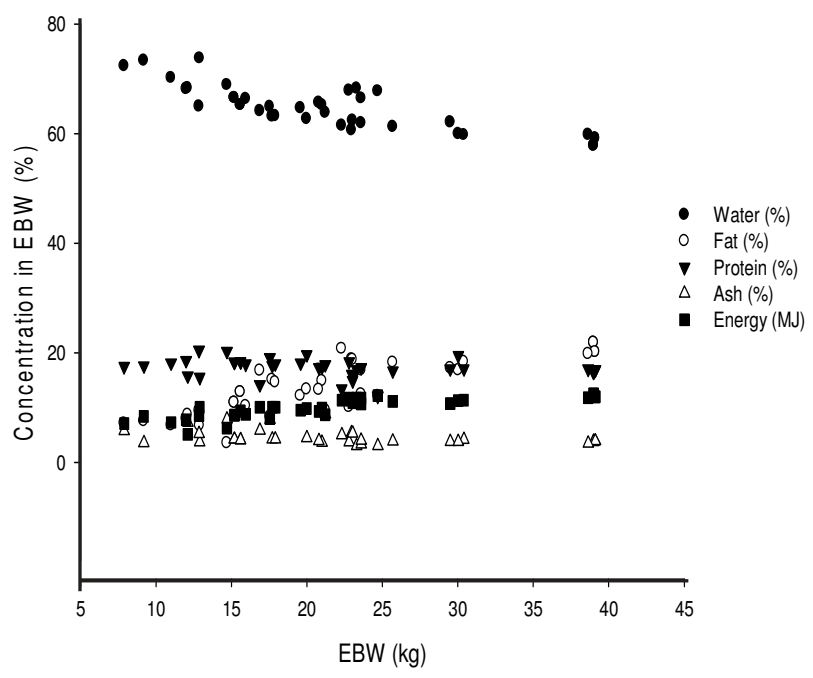

(Data from references: 7, 8, 22, 30, 34 and 38) 
Ecuación (3): \% agua $=72.881( \pm 1.022 * * *)-$ $0.385( \pm 0.044 * * *) \times \mathrm{PCV}(\mathrm{R} 2=0.67 ; \mathrm{CME}=$ $5,558 ; \mathrm{DER}=2.357 ; \mathrm{P}<0.0001 ; \mathrm{n}=39)$.

Ecuación (4): \% grasa $=3.62( \pm 1.22 * * *)+$ $0.460\left( \pm 0.05^{* * *}\right) \times \mathrm{PCV}(\mathrm{R} 2=0.67 ; \mathrm{CME}=$ 7.929; $\mathrm{DER}=2.815 ; \mathrm{P}<0.0001 ; \mathrm{n}=39)$.

Ecuación (5): Energía (MJ $/ \mathrm{kg} \mathrm{PCV})=3.322$ $\left( \pm 1.108^{* * *}\right)+0.449( \pm 0.098 * * *) \times \mathrm{PCV}-0.006$ $( \pm 0.002 * * *) \times \mathrm{PCV} 2(\mathrm{R} 2=0,71 ; \mathrm{CME}=0.976$; $\mathrm{DER}=0.988 ; P<0.0001 ; \mathrm{n}=39)$. Sin embargo, no se ajustaron ecuaciones para proteína cruda y cenizas del cuerpo.

\section{CONCLUSIONES E IMPLICACIONES GENERALES}

Existen pocos estudios disponibles sobre la evaluación de los requerimientos nutricionales de los ovinos de pelo. Los estudios encontrados muestran gran variación con respecto a los requerimientos de energía para los ovinos, siendo el promedio de EMm para hembras de $419 \pm 129 \mathrm{~kJ} / \mathrm{kg}$ PC0.75 y para machos $388 \pm$ $123 \mathrm{~kJ} / \mathrm{kg} P \mathrm{PC}^{0.75}$. La eficacia de la utilización de EM para mantenimiento $\left(K_{m}\right)$ y ganancia $\left(K_{g}\right)$ fueron $0.66 \pm 0.02$ y $0.42 \pm 0.04$, respectivamente.

Algunos autores han informado que estos requerimientos son en algunos casos superiores en comparación con los reportados previamente en sistemas energéticos de América del Norte y Europa para razas de lana $(15,23,24,42)$. Sin embargo, otros autores han reportado que estos requerimientos son más bajos en comparación con esos sistemas. Información con respecto a requerimientos de EM para mantenimiento y producción, y la variación existente en esas estimaciones es escasa para las razas de ovinos de pelo. Se ha informado que es probable que existan diferencias en los requisitos de EM para mantenimiento en ovinos de diferentes razas y tipos (de pelo vs lana); si esto es así, entonces habria una oportunidad para seleccionar las ovejas con el más bajo requerimiento de EM para mantenimiento y con ello, aumentar la from $11.20 \mathrm{MJ} / \mathrm{kg}$ and $208.54 \mathrm{~g} / \mathrm{kg}$ to 13.54 $\mathrm{MJ} / \mathrm{kg}$ and $274.95 \mathrm{~g} / \mathrm{kg}$ of EBW, respectively, as the BW increased from 13.0 to $28.70 \mathrm{~kg}$.

Using the data obtained in the present review, the body composition of hair sheep was plotted against the EBW, and three equations were fitted to predict body composition (Figure 1). The equations fitted were:

Equation (3): \% Water $=72.881\left( \pm 1.022^{* * *}\right)$ $0.385( \pm 0.044 * * *) \times \mathrm{EBW}\left(\mathrm{R}^{2}=0.67 ; \mathrm{MSE}=\right.$ 5.558; RSD $=2.357 ; P<0.0001 ; \mathrm{n}=39)$.

Equation (4): \% Fat $=3.62( \pm 1.22 * * *)+0.460$ $\left( \pm 0.05^{* * *}\right) \times$ EBW $\left(\mathrm{R}^{2}=0.67 ; \mathrm{MSE}=7.929\right.$; $\mathrm{RSD}=2.815 ; \mathrm{P}<0.0001 ; \mathrm{n}=39)$.

Equation (5): Energy (MJ/kg EBW) $=3.322$ $\left( \pm 1.108^{* * *}\right)+0.449\left( \pm 0.098^{* * *}\right) \times \mathrm{EBW}-0.006$ $( \pm 0.002 * * *) \times E B W^{2}\left(\mathrm{R}^{2}=0.71 ; \mathrm{MSE}=0.976\right.$; $\mathrm{RSD}=0.988 ; P<0.0001 ; \mathrm{n}=39$ ). Nonetheless, for body crude protein and ash, no equations were adjusted.

\section{GENERAL CONCLUSIONS AND IMPLICATIONS}

There are few studies available concerning the assessment of the nutrient requirements of hair sheep. Those studies show great variation regarding the energy requirements for ewes, being the average $\mathrm{ME}_{\mathrm{m}} 419 \pm 129 \mathrm{~kJ} / \mathrm{kg} \mathrm{BW} 0.75$ and for the male $388 \pm 123 \mathrm{~kJ} / \mathrm{kg} \mathrm{BW} 0.75$. The efficiency of ME utilization for maintenance $\left(k_{m}\right)$ and gain $\left(k_{g}\right)$ were $0.66 \pm 0.02$ and $0.42 \pm$ 0.04 , respectively.

Some authors have reported that such requirements are in some cases higher compared to those previously reported in North American and European energy systems $(15,23,24,42)$ for wool breeds. However, other authors have reported that these requirements are lower compared to those systems. Information regarding ME requirements for maintenance and production and the variation existing in such estimates is scarce for the breeds of hair sheep. 
eficiencia de la producción de corderos. Por lo tanto, es importante determinar las necesidades de energía de diferentes razas de ovinos de pelo y la eficiencia con la que utilizan la EM absorbida desde el tracto gastrointestinal. Para desentrañar algunas de los cuestionamientos anteriores, será necesario construir una unidad calorimétrica en México con la infraestructura adecuada y equipos para medir indirectamente el calor resultante de las diferentes fuentes en el animal. Esta instalación no necesariamente ha de ser extremadamente costosa, las cajas de cabeza para mediciones calorimétricas en cabras del Instituto de investigación en la Universidad de Langston "Kika de la Garza", Estados Unidos, son un buen ejemplo de una unidad calorimétrica de bajo costo, eficiente, para pequeños rumiantes.

Esta revisión intentó identificar las áreas potenciales de investigación donde se requieren los conocimientos fundamentales para aumentar la eficiencia energética de producción de ovinos de pelo en las regiones tropicales de América Latina. Parece evidente que debe hacerse hincapié en enfoques experimentales que permitan la identificación de animales con el más bajo consumo residual y requerimientos de energía para mantenimiento, así como la mayor eficiencia de utilización de EM para mantenimiento, aumento de peso, gestación y lactancia. El conocimiento de estos valores puede ayudar a los nutricionistas a formular raciones prácticas con una mejor base científica que en la actualidad. La identificación e incorporación de las ovejas más eficientes en los sistemas de producción puede eventualmente, causar un aumento en la productividad y rentabilidad para los agricultores de los países en desarrollo de las regiones tropicales del mundo.

\section{LITERATURA CITADA}

1. López-Carlos MA, Ramírez RG, Aguilera-Soto JI, Aréchiga $\mathrm{CF}$, Rodríguez $\mathrm{H}$. Size and shape analyses in hair sheep ram
It has been reported that it is likely that differences exist in the ME requirements for maintenance in ewes of different breeds and type (hair vs wool); if this is so, then there would be an opportunity to select those ewes with the lowest ME requirement for maintenance and with this, increase the efficiency of mutton production. Thus, it is important to determine the energy requirement of different breeds of hair sheep and the efficiency with which they utilize ME absorbed from the gastrointestinal tract. To unravel some of the questions above, it will be required to build a calorimetric unit in Mexico with the appropriate infraestructure and equipment to measure indirectly heat arising from the different sources within the animal. This facility has not necessarily be extremely expensive, the head-boxes for calorimetric measurements in goats at the "Kika de la Garza" Research Institute in Langston University, United States, are a good example of a low-cost, efficient, calorimetric unit for small ruminants.

This review attempted to identify potential areas of research where fundamental knowledge is required in order to increase energetic efficiency of hair sheep production in the tropical regions of Latin America. It seems apparent that emphasis must be given to experimental approaches which allow identification of animals with the lowest residual feed intake and energy requirement for maintenance as well as the highest efficiency of ME utilization for maintenance, weight gain, pregnancy and lactation. The knowledge of those values may help nutritionists to formulate practical rations with a better scientific base than at present. The identification and incorporation of the most efficient sheep in production systems may eventually lead to an increase in productivity and profitability for farmers in developing countries of the tropical regions of the world.

End of english version

lambs and its relationships with growth performance. Livest Sci 2010;(131):203-211. 
2. Cantón GCJ, Bores QR, Baeza RJ, Quintal FJ, Santos RR, Sandoval CC. Energy retention of F1 Pelibuey lambs crossed with breeds for meat production. J Anim Vet Adv 2009;8(12):2655-2661.

3. Cantón J, Moguel Y, Castellanos A. Estimación del requerimiento energético de mantenimiento del borrego Pelibuey en clima tropical. Téc Pecu Méx 1995;(33):66-73.

4. Silva A, da Silva Sobrinho A, Trindade I, Resende K, Bakke $O$. Net requirements of protein and energy for maintenance of wool and hair lambs in tropical region. Small Rum Res 2003;(49):165-171.

5. Cabral LDS, Neves EMDO, Zervoudakis JT, Abreu JGD, Rodrigues RC, Souza AL, et al. Estimativas dos requisitos nutricionais de ovinos em condições brasileiras. Rev Bras Saúde Prod Anim 2008;9(3):529-542.

6. Duarte VF, Sandoval CA, Sarmiento LA. Empleo del modelo SRNS para predecir la ganancia de peso en ovinos machos Pelibuey en crecimiento. Arch Zootec 2009;58(224):671681.

7. Silva AMA, Santos EM, Filho JMP, Bakke OA, Gonzaga NS, Costa RG. Body composition and nutritional requirements of protein and energy for body weight gain of lambs browsing in a tropical semiarid region. Rev Bras Zootec 2010;(39):210-216.

8. Gonzaga-Neto SA, da Silva-Sobrinho AG, de Resende $K T$, Zeola NMBL, de Azevedo-Silva AM, Marques CAT, et al. Composição corporal e exigências nutricionais de proteína e energia para cordeiros Morada Nova. Rev Bras Zootec 2005;(34):2446-2456.

9. Resende KT, Silva HGO, de-Lima LD, Teixeira IAMA. Avaliação das exigências nutricionais de pequenos ruminantes pelos sistemas de alimentação recentemente publicados. Rev Bras Zootec 2008;37(Supl esp):161-177.

10. Vieira PAS, Pereira LGR, Azevêdo JAG, Neves ALA, Chizzotti $\mathrm{ML}$, dos Santos et al. Development of mathematical models to predict dry matter intake in feedlot Santa Ines rams. Small Rumin Res 2013;112(1):78-84.

11. Chay-Canul AJ, Espinoza-Hernández JC, Ayala-Burgos AJ, Magaña-Monforte JG, Aguilar-Pérez CF, Chizzotti ML, et al. Relationship of empty body weight with shrunken body weight and carcass weights in adult Pelibuey ewes at different physiological states. Small Ruminant Res 2014;(117):10-14.

12. Tedeschi LO, Cannas A, Fox DG. A nutrition mathematical model to account for dietary supply and requirements of energy and nutrients for domesticated small ruminants: The development and evaluation of the Small Ruminant Nutrition System. Small Ruminant Res 2010;(89):174-184.

13. Chay-Canul AJ, Ayala-Burgos AJ, Kú-Vera JC, MagañaMonforte JG, Tedeschi L. O. The effects of metabolizable energy intake on body fat depots of adult Pelibuey ewes fed roughage diets under tropical conditions. Trop Anim Health Prod 2011;(43):929-936.

14. Chilliard $Y$, Bocquier F, Doreau M. Digestive and metabolic adaptations of ruminants to undernutrition, and consequences on reproduction. A review. Reprod Nutr Dev $1998 ;(38): 129-150$.

15. NRC. Nutrient requirements of small ruminants: Sheep, goats, cervids, and New World camelids, 6th ed. Washington, DC: National Academy Press; 2007.
16. Cannas A, Tedeschi LO, Fox DG, Pell AN, Van Soest PJ. A mechanistic model for predicting the nutrient requirements and feed biological values for sheep. J Anim Sci 2004;(82):149-169.

17. Duarte VF, Sandoval CA, Sarmiento LA. Evaluación del modelo CNSPS-S para predecir el crecimiento del borrego Pelibuey. Rev Cient-Fac Cien V FCV-LUZ 2008;(18):296-304.

18. Regadas-Filho JGL, Pereira ES, Villarroel ABS, Pimentel PG, Fontenele RM, Costa MRGF, et al. Efficiency of metabolizable energy utilization for maintenance and gain and evaluation of Small Ruminant Nutrition System model in Santa Ines sheep. Rev Bras Zootec 2011;(40):2558-2564.

19. Maia ISG, Pereira ES, Pinto AP, Mizubuti IY, de AzambujaRibeiro EL, et al. Consumo, avaliação do modelo Small Ruminant Nutrition System e predição da composição corporal de cordeiros Santa Inês alimentados com rações contendo diferentes níveis de energia. Semina: Sci Agric 2014;35(4):2579-2596.

20. Oliveira AP, Pereira ES, Pinto AP, de Azevêdo-Silva AM, de Souza-Carneiro M S, Mizubuti IY. et al. Estimativas dos requisitos nutricionais e utilização do modelo Small Ruminant Nutrition System para ovinos deslanados em condições semiáridas. Semina: Sci Agric 2014;35(4):1985-1998.

21. Costa MRGF, Pereira ES, Pinto AP, de Azevêdo Silva AM, de Medeiros AN, et al. Prediction of body chemical composition of Morada Nova lambs using the composition of ribs section between 9th and 11th. Semina: Sci Agric 2014;35(4):20192032.

22. Regadas-Filho JGL, Pereira ES, Pimentel PG, Villarroel ABS, Medeiros AN, Fontenele RM. Body composition and net energy requirements for Santa Ines lambs. Small Ruminant Res 2013;(109):107-112.

23. ARC. The nutrient requirements of ruminant livestock. Agr Res Council. London: Gresham Press; 1980.

24. AFRC. Technical Committee on Responses to Nutrients. Energy and protein requirements of ruminants. $C A B$ International, Wallingford, UK; 1993.

25. Cannas A, Atzori AS, Teixeira IAMA, Sainz RD, Oltjen JW. The energetic cost of maintenance in ruminants: from classical to new concepts and prediction systems. In: Crovetto $M$ editor. Energy and protein metabolism and nutrition. Netherlands: Wageningen Academic Publishers; 2010;531-542.

26. Pereira ES, Fontenele RM, Silva AM, Oliveira RL, Ferreira MR, Mizubuti IY, et al. Body composition and net energy requirements of Brazilian Somali lambs. Ital J Anim Sci 2014;13(4):880-886.

27. Reynolds CK, Crompton LA, Mills JAN. Improving the efficiency of energy utilization in cattle. Anim Prod Sci 2011;(51):6-12.

28. Ferrell CL. And Oltjen JW. ASAS CENTENNIAL PAPER: Net energy systems for beef cattle- Concepts, application, and future models. J Anim Sci 2008;(86):2779-2794.

29. Tolkamp BJ. Efficiency of energy utilization and voluntary feed intake in ruminants. Animal 2010;(4):1084-1092.

30. Galvani DB, Pires AV, Susin I, Gouvêa VN, Berndt A, Chagas LJ, et al. Energy efficiency of growing ram lambs fed concentrate-based diets with different roughage sources. J Anim Sci 2014;92(1):250-263. 


\section{REQUERIMIENTOS ENERGÉTICOS DE OVINOS DE PELO EN REGIONES TROPICALES DE LATINOAMÉRICA}

31. Chay-Canul AJ, Ayala-Burgos AJ, Kú-Vera JC, MagañaMonforte JG, Ferrell CL. Metabolizable energy intake and changes in body weight and body condition of Pelibuey ewes fed three levels of roughage diets under tropical conditions. Trop Subtrop Agroecosyt 2011;(14):777-786.

32. Duarte F, Sandoval-Castro CA, Sarmiento-Franco LA, Tedeschi LO, Santos-Ricalde RH. Energy and protein requirements of growing Pelibuey sheep under tropical conditions estimated from a literature database analyses. Trop Subtrop Agroecosyt 2012;15(1):97-103.

33. Chávez RG, Castellanos RA, Velásquez MP. Producción de las ovejas Pelibuey pre y posparto alimentadas con diversos aportes nutricionales. Tec Pecu Mex 1995;(33):183-191.

34. Costa MRGF, Pereira ES, Silva AMA, Paulino PVR, Mizubuti IY, Pimentel PG, et al. Body composition and net energy and protein requirements of Morada Nova lambs. Small Ruminant Res 2013;114(2):206-213.

35. Tedeschi LO, Fox DG, Carstens GE, Ferrell CL. The partial efficiency of use of metabolisable energy for growth in ruminants. In: Crovetto $\mathrm{M}$, editor. Energy and protein metabolism and nutrition. Netherlands: Wageningen Academic Publishers; 2010:519-529.

36. Marcondes MI, Chizzotti ML, Valadares-Filho SC, Gionbelli MP, Paulino PVR, Paulino MF. Energy requirements of Zebu beef cattle. In: Valadares FS. et al editors. Nutrient requirements of Zebu beef cattle, BR. Corte. $2^{\text {nd }}$ ed. Federal University of Vicosa, MG; UFV, DZO, Brasil. 2010;81-106.

37. Chizzotti ML, Tedeschi LO, Valadares-Filho SC. A metaanalysis of energy and protein requirements for maintenance and growth of Nellore cattle. J Anim Sci 2008;86(7):15881597.

38. Oliveira NA, Pérez JRO, Carvalho PA, Paula OJ, Baião EAM. Composição corporal e exigências líquidas em energia e proteína para ganho de cordeiros de quatro grupos genéticos. Ciênc Agrotéc 2004;(28):1169-1176.

39. Solís RG, Castellanos RA, Velázquez MA, Rodríguez GF. Determination of nutritional requirements of growing hair sheep. Small Ruminant Res 1991;(4):115-125.

40. Ramírez RG, Huerta J, Kawas JR, Alonso DS, Mireles E, Gómez MV. Performance of lambs grazing in a buffelgrass (Cenchrus ciliaris) pasture and estimation of their maintenance and energy requirements for growth. Small Ruminant Res 1995;(17):117-121.

41. Fernandes MHMR, Resende KT, Tedeschi LO, Fernandes-Jr JS, Teixeira IAMA, Carstens GE, et al. Predicting the chemical composition of the body and the carcass of $3 / 4$ Boer $x 1 / 4$ Saanen kids using body components. Small Ruminant Res 2008; (75):90-98.

42. NRC. Nutrient requirements of sheep. 6th ed. Washington, DC: National Academy Press; 1985. 
